\title{
アクティブ吸振器付き移動ロボットによる液体タンクの制振制御 一液面振動の逆モデルを利用した制振法—
}

\author{
浜口雅 史*.谷口隆 雄* \\ Damping Control of Liquid Container by Swing-type Active Vibration Reducer on Mobile Robot \\ - Damping Control Method by Using Inverse Model of Sloshing- \\ Masafumi HamaguCHI* and Takao TANiguCHI*
}

\begin{abstract}
This paper proposes a damping control of sloshing in a cylindrical container with a swing-type active vibration reducer on a wheeled mobile robot (WMR). The WMR runs along a straight path on a horizontal plane. The container is mounted on the active vibration reducer. A laser displacement sensor is used to observe the liquid level in the container. The container can be tilted in the running direction by the active vibration reducer. A sloshing model is obtained from a spherical pendulum-type sloshing model, which approximately expresses (1, 1)-mode sloshing. The sloshing model is used to design a damping control system. The control system of the active vibration reducer is designed with an inverse model of sloshing and an optimal regulator with a Kalman filter. The WMR is driven by an acceleration pattern designed with an input shaping method. The usefulness of the proposed method is demonstrated through simulation and experimental results.
\end{abstract}

Key Words: damping control, sloshing, wheeled mobile robot, active vibration reducer

\section{1.はじめに}

鉄鋼・鋳造業における溶融金属搬送やパイプレス化学プラ ントにおける混合液搬送などの液体タンク搬送では, 搬送時 の液面振動（スロッシング）を抑制し，かつ高速に液体タン クを搬送する自動化が望まれている。

液体搬送に関する研究として, 固定レール上の搬送を対象 としたものがある ${ }^{1) \sim 5)}$. しかし，これらは固定レール上を走 行するため, 搬送工程の変化に迅速に対応することが困難で

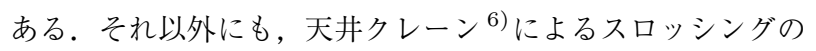
制振搬送に関する研究がある. 天井クレーンは, 空間を有効 利用できるが設置コストが高いという久点がある．設置コス トが低く, 搬送経路を容易に変更できることから, 車輪型移 動ロボットや搬送車による液体搬送に関する研究も行なわれ ている7) 9). また, 著者らは, 制振性能を高めるために, 2 軸回転式アクティブ吸振器を移動ロボットに取り付け, 制振 搬送制御を行なった ${ }^{10)}$. しかし，これはフィードバック補償 器のみを使用しており, スロッシングの制振性能が十分であ るとはいえないものであった。

よって, 本論文では, フィードフォワード補償器を付加す

* 島根大学総合理工学部 松江市西川津町 1060

* Interdisciplinary Faculty of Science and Engineering, Shimane University, 1060 Nishikawatsu, Matsue

(Received March 18, 2011)

(Revised June 8, 2011)
ることにより, 回転式アクティブ吸振器付き移動ロボットに よる液体タンクの制振制御における制振性能の向上を図るこ とを目的とする。ただし，ここでは，移動ロボットは水平面 上の直線軌道を走行するものとする。

\section{2. 実験装 置}

実験装置を Fig. 1 に示す．移動ロボット上の 2 軸回転式 アクティブ吸振器により, 円筒液体タンクは進行方向と横方 向へ独立に傾斜させることができる，ただし，ここでは，直 進経路走行のみを考えるため, 進行方向の吸振器のみを動作 させ, 横方向の吸振器は使用しない. タンクの内径は $0.10 \mathrm{~m}$, 高さ $0.30 \mathrm{~m}$ であり，この中に液位が $0.10 \mathrm{~m}$ になるまで水を 注入する. タンクの傾斜角は, 各回転軸に取り付けたロー夕 リーエンコーダにより検出される，後方壁近傍の液位変動量 はレーザ変位計により観測される。これらのセンサ值は DSP ボードへ入力され, 制御則によって算出された吸振器への指 令值が DSP ボードから出力される。一方, 移動ロボットに は, 走行速度ならびに走行経路の曲率が与えられる，与えら れたと㧍りに走行するよう, PID 制御系によって左右動輪の 回転速度ならびに操舵輪の舵角が制御される. 左右動輪の回 転角はロータリーエンコーダで, 操舵輪の舵角はポテンショ メータで測定される．移動ロボットの走行加速度は加速度セ ンサにより計測される，なお，移動ロボットは， 2 駆動輪と 1 操舵輪をもつ 3 輪車型である. 


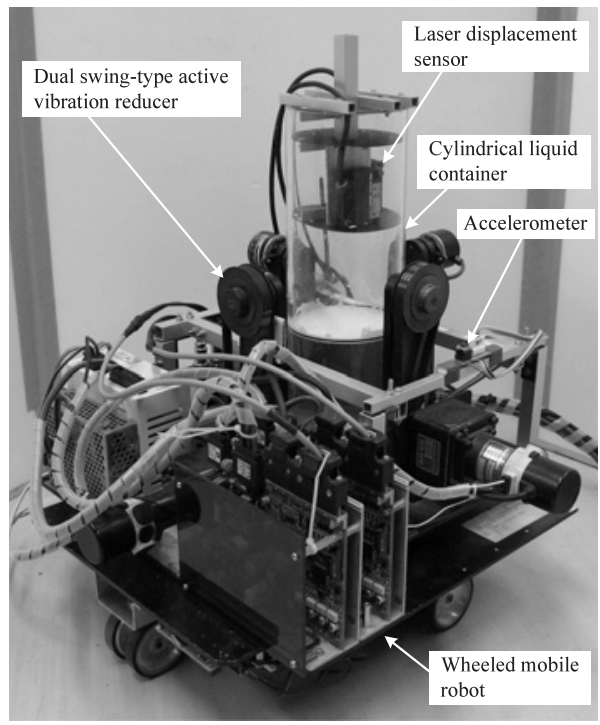

Fig. 1 Experimental equipment

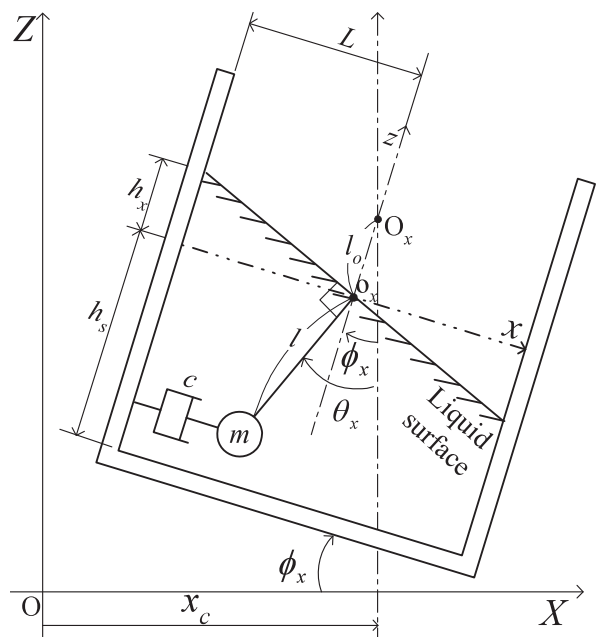

Fig. 2 Pendulum-type sloshing model in $X$-direction

\section{3. システムモデル}

本論文で使用する $X-Z$ 平面における単振子型スロッシン グモデルを Fig. 2 に示す。ここで， $X$ 軸が移動ロボットの 走行方向を, $Z$ 軸が鉛直方向を表わす．対象とするスロッシ ングモードは，走行状態において最も影響を及ぼす 1 次モー ドスロッシングとし，液面を直線で近似した。 $\mathrm{O}_{x}$ 点周りの モーメントの釣り合いを考え, 線形近似を行ない, 次式を得 る $^{2), 5)}$

$$
\begin{aligned}
\ddot{\theta}_{x}= & -\frac{g}{l} \theta_{x}-\frac{c}{m} \dot{\theta}_{x}+\left(\frac{c}{m}+\frac{l_{o}}{T_{x} l}\right) \dot{\phi}_{x} \\
& -\frac{K_{x} l_{o}}{T_{x} l} u_{x}+\frac{1}{l} a_{x}
\end{aligned}
$$

ここで, $\theta_{x}$ は振子角度, $\phi_{x}$ は夕ンク角度, $c$ は粘性係数, $m$ は 振子質量 (=タンク内液体質量), $g$ は重力加速度, $l$ は振子長, $l_{o}$ はタンク回転中心 $\mathrm{O}_{x}$ と振子支点 $\mathrm{o}_{x}$ 間の距離, $a_{x}\left(=\ddot{x}_{c}\right)$ は移動ロボットの走行加速度である。なお, アクティブ吸振
Table 1 Actual values in system parameters

\begin{tabular}{|c|c|}
\hline$c[\mathrm{Ns} / \mathrm{m}]$ & 1.27 \\
\hline$l[\mathrm{~m}]$ & 0.0252 \\
\hline$m[\mathrm{~kg}]$ & 0.7854 \\
\hline$l_{o}[\mathrm{~m}]$ & 0.0500 \\
\hline$L[\mathrm{~m}]$ & 0.0255 \\
\hline$T_{x}[\mathrm{~s}]$ & 0.0078 \\
\hline$K_{x}[\mathrm{rad} /(\mathrm{Vs})]$ & 0.1785 \\
\hline
\end{tabular}

器の入力電圧 $u_{x}$ からタンク角速度 $\dot{\phi}_{x}$ までの伝達関数は, 次 式の 1 次遅れ系で近似した。

$$
G_{x}(s)=\frac{\dot{\phi}_{x}}{u_{x}}=\frac{K_{x}}{T_{x} s+1}
$$

ここで， $T_{x}$ は時定数， $K_{x}$ はゲインである，なお，本論文で は，伝達関数が含まれる式中において，表記上，入出力なと の信号は時間領域のものを使用するが，実際には，ラプラス 変換された信号を表わす。

液位変動量 $h_{x}$ は

$$
h_{x}=L\left(\theta_{x}-\phi_{x}\right)
$$

で与えられる。ここで，Lはタンク中心から測定点までの距 離である。

したがって， $X-Z$ 平面におけるシステム方程式は

$$
\left.\begin{array}{l}
\dot{\boldsymbol{x}}_{x}=\boldsymbol{A}_{x} \boldsymbol{x}_{x}+\boldsymbol{b}_{x} u_{x}+\boldsymbol{d}_{x} a_{x} \\
\boldsymbol{y}_{x}=\boldsymbol{C}_{x} \boldsymbol{x}_{x}
\end{array}\right\}
$$

となる。ここで

$$
\begin{aligned}
& \boldsymbol{A}_{x}=\left[\begin{array}{cccc}
0 & 1 & 0 & 0 \\
-\frac{g}{l} & -\frac{c}{m} & 0 & \frac{c}{m}+\frac{l_{o}}{T_{x} l} \\
0 & 0 & 0 & 1 \\
0 & 0 & 0 & -\frac{1}{T_{x}}
\end{array}\right] \\
& \boldsymbol{b}_{x}=\left[\begin{array}{c}
0 \\
-\frac{K_{x} l_{o}}{T_{x} l} \\
0 \\
-\frac{K_{x}}{T_{x}}
\end{array}\right], \boldsymbol{C}_{x}=\left[\begin{array}{cccc}
L & 0 & -L & 0 \\
0 & 0 & 1 & 0
\end{array}\right] \\
& \boldsymbol{d}_{x}=\left[\begin{array}{c}
0 \\
\frac{1}{l} \\
0 \\
0
\end{array}\right], \boldsymbol{x}_{x}=\left[\begin{array}{l}
\theta_{x} \\
\dot{\theta}_{x} \\
\phi_{x} \\
\dot{\phi}_{x}
\end{array}\right], \boldsymbol{y}_{x}=\left[\begin{array}{l}
h_{x} \\
\phi_{x}
\end{array}\right]
\end{aligned}
$$

である。スロッシングならびに吸振器に関するパラメータは, 過渡応答法によって同定した，本実験装置における各種パラ メータ值を Table 1 に示す.

実際の制御には, (4) 式をサンプリング時間 $\delta t$ で離散化し た次式の離散時間系モデルを用いる。

$$
\left.\begin{array}{l}
\boldsymbol{x}_{x}(k+1)=\boldsymbol{P}_{x} \boldsymbol{x}_{x}(k)+\boldsymbol{q}_{x} u_{x}(k) \\
\boldsymbol{y}_{x}(k)=\boldsymbol{C}_{x} \boldsymbol{x}_{x}(k)
\end{array}\right\}
$$


ここで

$$
\boldsymbol{P}_{x}=\exp \left(\boldsymbol{A}_{x} \delta t\right), \boldsymbol{q}_{x}=\int_{0}^{\delta t} \exp \left(\boldsymbol{A}_{x} \tau\right) d \tau \boldsymbol{b}_{x}
$$

である.本論文では， $\delta t=1.0 \mathrm{~ms}$ とした.

\section{4. 制振制御系}

スロッシングの逆モデルを利用したフィードフォワード補 償器, ならびに最適レギュレータによるフィードバック補償 器の設計方法について説明する。

\section{1 スロッシングの逆モデルを利用したフィードフォワー} ド補償器

移動ロボットの加速度 $a_{x}$ を入力, 振子角度 $\theta_{x}$ を出力とす る伝達関数を $G_{1}(s)$, 吸振器への入力電圧 $u_{x}$ を入力, 振子 角度 $\theta_{x}$ を出力とする伝達関数を $G_{2}(s)$, 吸振器への入力電圧 $u_{x}$ を入力, タンク角度 $\phi_{x}$ を出力とする伝達関数を $G_{3}(s)$ と おくと，(1)，(2) 式より

$$
\begin{aligned}
& G_{1}(s)=\frac{\theta_{x}}{a_{x}}=\frac{\frac{1}{l}}{s^{2}+\frac{c}{m} s+\frac{g}{l}} \\
& G_{2}(s)=\frac{\theta_{x}}{u_{x}}=\frac{-\frac{K_{x} l_{o}}{l} s+\frac{K_{x} c}{m}}{\left(s^{2}+\frac{c}{m} s+\frac{g}{l}\right)\left(T_{x} s+1\right)} \\
& G_{3}(s)=\frac{\phi_{x}}{u_{x}}=\frac{K_{x}}{s\left(T_{x} s+1\right)}
\end{aligned}
$$

となる，液位変動量 $h_{x}$ は，(3) 式ならびに $(8) \sim(10)$ 式より 次式のように表わされる.

$$
h_{x}=L\left(G_{1}(s) a_{x}+\left(G_{2}(s)-G_{3}(s)\right) u_{x}\right)
$$

上式より, 液位変動量 $h_{x}=0$ とする吸振器の入力電圧 $u_{x}^{*}$ は 次式となる。

$$
u_{x}^{*}=-\left(G_{2}(s)-G_{3}(s)\right)^{-1} G_{1}(s) a_{x}=C(s) a_{x}
$$

この $C(s)$ がフィードフォワード補償器となる。スロッシン グモデルにおいて，入力は移動ロボットの加速度と吸振器へ の入力電圧，出力は液位変動量である。ここでは，その逆モ デルを利用して，移動ロボットに加速度が加わった際に液位 変動量を零とする吸振器の入力電圧を求めた.

移動ロボットに加速度 $a_{x}$, 吸振器に入力電圧 $u_{x}^{*}$ が加わっ た際の振子角度 $\theta_{x}^{*}$ は

$$
\theta_{x}^{*}=G_{1}(s) a_{x}+G_{2}(s) u_{x}^{*}=G_{3}(s) u_{x}^{*}=\phi_{x}^{*}
$$

となる。つまり，振子角度 $\theta_{x}$ とタンク角度 $\phi_{x}$ を一致させる ことによって, 液位変動量 $h_{x}$ を零としている. $(8) \sim(10)$ 式 より, $C(s)$ は次式となる.

$$
C(s)=\frac{s\left(T_{x} s+1\right)}{K_{x}\left(\left(l+l_{o}\right) s^{2}+g\right)}
$$

ここで, $l, l_{o}, g>0$ より, $C(s)$ の極は複素 $s$ 平面の虚軸上 にあることがわかる。つまり，スロッシングの逆モデルを利
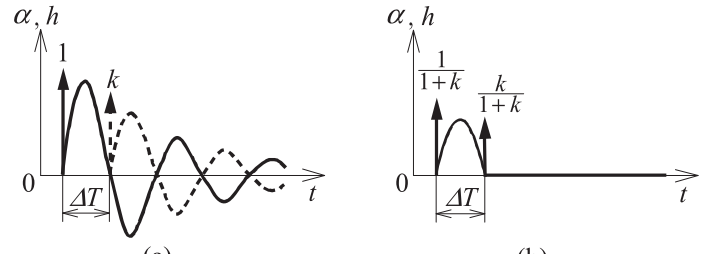

(a)

(b)

Fig. 3 2-impulse technique of input shaping method

用することによって液位変動量を零とすることができるが, 入力電圧 $u_{x}^{*}$ は非減衰振動となり，タンクは振動し続けるこ とになる。そこで, コントローラ $C(s)$ へ入力である移動 ロボットの加速度 $a_{x}$ を整形することにより，タンクの振動 をなくすことを考える。

移動ロボットの加速度 $a_{x}$ を入力, 吸振器の入力電圧 $u_{x}^{*}$ に よるタンク角度 $\phi_{x}^{*}$ を出力とする伝達関数 $G_{4}(s)$ は, $(10)$ 式, (12), (14) 式より

$$
G_{4}(s)=\frac{\phi_{x}^{*}}{a_{x}}=G_{3}(s) C(s)=\frac{1}{\left(l+l_{o}\right) s^{2}+g}
$$

となる.上式より, タンク角度の振動は 2 次遅れ系で表わさ

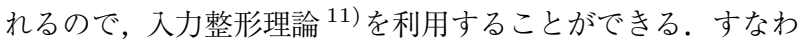
ち，入力整形理論を用いて移動ロボットの加速度を整形する ことにより，加減速終了時にタンク角度を零にすることがで きる。なお，(15) 式より， $u_{x}^{*}$ を入力すると夕ンクは $l+l_{o}$ の 振子長をもつ非減衰単振子と同じ挙動を示すことがわかる.

入力整形理論の原理を Fig. 3 に示す. Fig. 3(a) に示すよ うに単位インパルス入力により生じた振動を， $\Delta T$ 後に加え た大きさ $k$ のインパルス入力により生じる振動で相殺すると いうものである. 整形後の入力が Fig. 3(b) である.これは整 形前の入力と同じ大きさの入力になるように全体を $1+k$ で除 してある. システムの伝達関数が (16) 式で表わされるとき， $\Delta T$ ならびに $k$ は (17) 式で求められる ${ }^{11)}$.

$$
\begin{aligned}
& G(s)=\frac{K_{n} \omega_{n}^{2}}{s^{2}+2 \zeta \omega_{n} s+\omega_{n}^{2}}, \\
& \Delta T=\frac{\pi}{\omega_{n} \sqrt{1-\zeta^{2}}}, \quad k=\exp \left(\frac{-\zeta \pi}{\sqrt{1-\zeta^{2}}}\right),
\end{aligned}
$$

ここで， $\omega_{n}$ は固有角振動数， $\zeta$ は減衰係数， $K_{n}$ はゲインで ある。

Fig. 4 に示すように，台形加速度パターンに対して入力整 形理論を適用する. Fig. 4(a) の台形加速度パターンに入力整 形理論を適用したものが Fig. 4(b) である。この加速度パター ンで移動ロボットを走行させる．なお，(15)，(16) 式より， $\zeta=0, \omega_{n}=\sqrt{g /\left(l+l_{o}\right)}=11.42 \mathrm{rad} / \mathrm{s}$ となり，(17) 式よ $\eta, \Delta T=0.275 \mathrm{~s}, k=1$ となる。本論文のように $k=1$ の 場合， $t_{1}=\Delta T$ とすれば, Fig. 5 のように単純な台形加速度 パターンにすることができる，すなわち， $t_{a}=2 \Delta T$ である. Fig. 5 は，加速後，等速で走行し，減速後に停止する加速度 パターンであり，この加速度パターンを用いて移動ロボット を走行させる。 


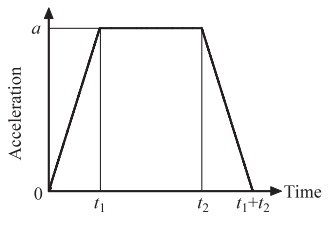

(a)

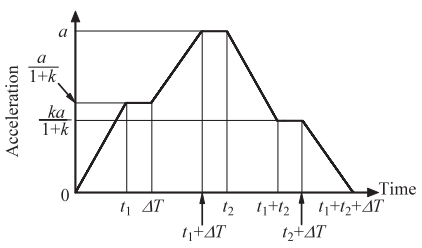

(b)
Fig. 4 Designed acceleration pattern with input shaping method

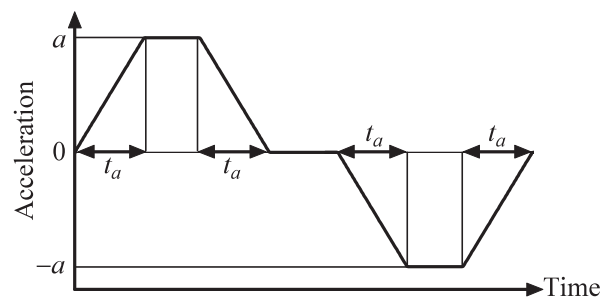

Fig. 5 Designed trapezoidal acceleration pattern of WMR

4.2 最適レギュレータによるフィードバック補償器の付加 スロッシングの逆モデルを利用したフィードフォワード補 償器のみでは，モデル化誤差や外乱に弱いという久点がある. これを解決するために，フィードバック補償器である最適レ ギュレータ ${ }^{12)}$ を制振制御系に付加することを考える．制振制 御系のブロック線図を Fig. 6 に示す．移動ロボットの加速度 $a_{x}$ としては, 入力整形理論によって整形されたものが入力さ れる．この加速度によって発生する液位変動量 $h_{x}$ を零とす る吸振器の入力電圧 $u_{x}^{*}$ が, フィードフォワード補償器 $C(s)$ によって生成される.この加速度 $a_{x}$ と入力電圧 $u_{x}^{*}$ が入力 されたときの状態 $\boldsymbol{x}_{x}$ を目標值とし, カルマンフィルタょり 推定された状態 $\hat{\boldsymbol{x}}_{x}$ を目標值に一致させるように，フィード バック補償が付加されている。レーザ変位計によって測定し た液位には，観測ノイズが混入しており，また，直接観測でき ない状態量を推定するため, カルマンフィルタを用いた ${ }^{12)}$. カルマンフィルタゲインは, システムノイズを零とし, 液位 変動量とタンク角度に関する観測ノイズ分散值をそれぞれ, $8.274 \times 10^{-5} \mathrm{~m}^{2}, 1.000 \times 10^{-10} \mathrm{rad}^{2}$ として求めた.

最適レギュレータのフィードバックゲイン $\boldsymbol{F}$ は, (18) 式 の離散形 2 次形式評価関数 $J$ を最小化することにより求めら れる。

$$
J=\sum_{k=0}^{\infty}\left(\left\|\boldsymbol{x}_{x}(k)\right\|_{\boldsymbol{Q}_{e}}^{2}+\left\|u_{x}(k)\right\|_{r_{e}}^{2}\right)
$$

離散形 2 次形式評価関数 $J$ の重み行列は, 以下のように与

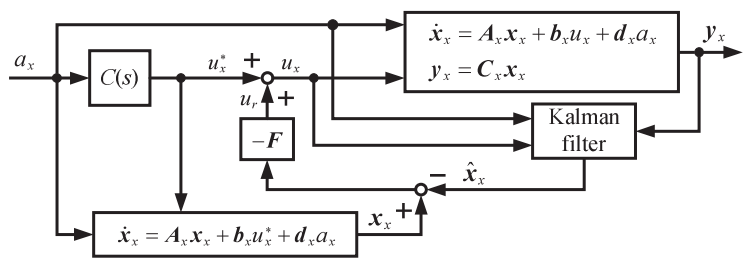

Fig. 6 Damping control system
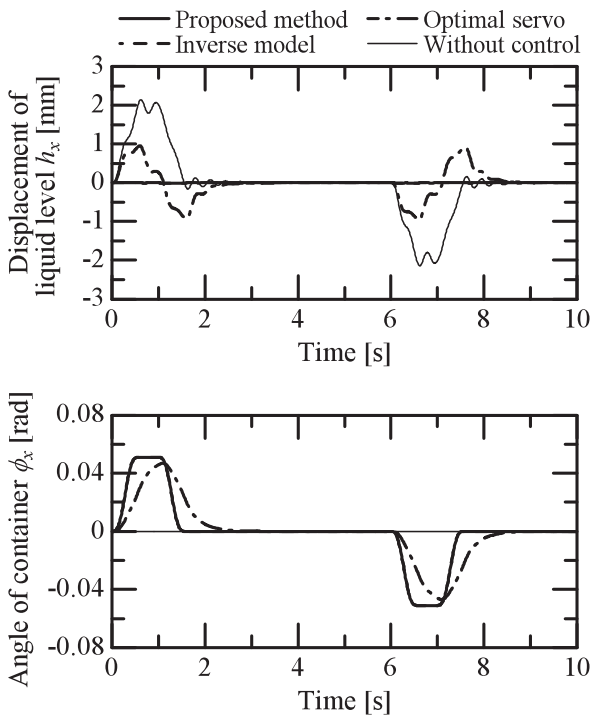

Fig. 7 Simulation results of damping control

えた。

$$
\boldsymbol{Q}_{e}=\boldsymbol{C}_{x}^{\mathrm{T}} \boldsymbol{W} \boldsymbol{C}_{x}, \quad r_{e}=1.0
$$

ここで，W は，液位変動量とタンク角度に関する重み行列 である。制御シミュレーションならびに実験を行ない，この 重み行列の值を (20) 式のように決定した。 なお，スロッシン グの制振を重視するため，液位変動量に関する重みのほうを 大きくした。

$$
\boldsymbol{W}=\operatorname{diag}\left(5.0 \times 10^{5}, 10\right)
$$

\section{5. 制振制御結果}

提案手法を用いて, 液体タンクの制振搬送制御を行なった. まず，シミュレーション結果を示し，つぎに実験結果を示す.

5.1 制御シミュレーション結果

制振制御のシミュレーション結果を Fig. 7 に示す. 移動 ロボットの最大加速度は $a=0.5 \mathrm{~m} / \mathrm{s}^{2}$, 等速走行時の速度 は $0.5 \mathrm{~m} / \mathrm{s}$ である。なお，比較のために，1) 逆モデルを利用 したフィードフォワード補償器と最適レギュレータのフィー ドバック補償器の併用（提案手法），2）逆モデルを利用した フィードフォワード補償器のみ，3) 最適サーボ ${ }^{10)}$, 4) 無制 御の 4 通りの結果を併せて示してある。無制御時の結果は, 吸振器を動作させず, $t_{a}=0.5 \mathrm{~s}$ とした Fig. 5 の台形加速度パ ターンで移動ロボットを走行させたときのものである。この ときの $t_{a}$ の值が，入力整形理論を用いて整形した台形加速度 パターンの值 $(2 \Delta T=0.55 \mathrm{~s})$ に近いため，あまり振動的で はなくなっている．搬送終了時間を制御ありのものと同程度 とするために，無制御時の $t_{a}$ の值を $0.5 \mathrm{~s}$ としたが，この值 を変えれば，より振動的な結果となる．Fig. 7 より，提案手 法を用いれば，液位変動量は完全に零となり，タンク角度も 加減速終了後に速やかに零とすることができる，なお，逆モ デルを利用したフィードフォワード補償器のみの結果と提案 


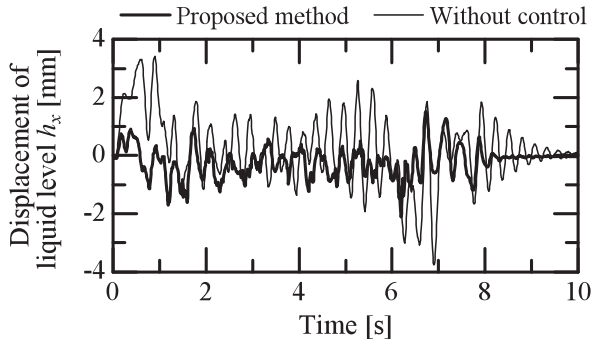

(a) Proposed method

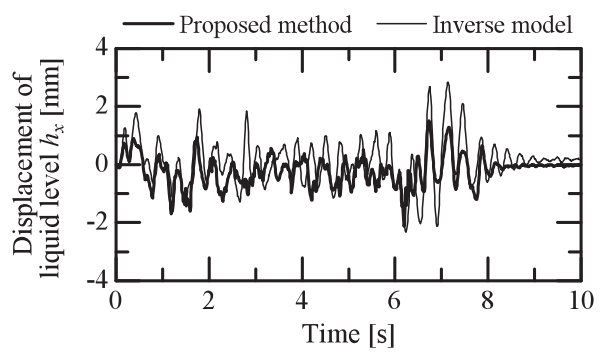

(b) Compared with only inverse model

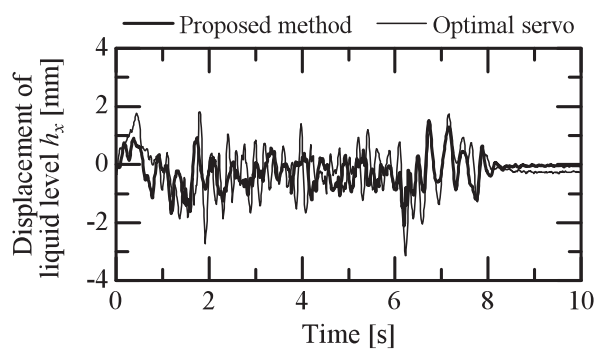

(c) Compared with optimal servo

Fig. 8 Experimental results of displacement of liquid level with damping control

手法の結果は完全に一致している。これは，シミュレーショ ン上では，モデル化誤差や外乱を加えていないためである.

\section{2 制御実験結果}

制振制御の実験結果を Fig. 8 ならびに Fig. 9 に示す. Fig. 8 は液位変動量, Fig. 9 は夕ンク角度を表わしている. Fig. 8(a) より，提案手法は無制御のものより高い制振効果を 得ていることがわかる。このときのタンク角度のようすを示 したものが Fig. 9(a) である. 加減速時に, タンクを大きく傾 け，等速走行時ならびに停止時にはタンク角度を零に保持し ている.

Fig. 8(b) では, 提案手法と, 逆モデルを利用したフィード フォワード補償器のみを用いたものとの比較を行なった。同 図より，提案手法のほうがより高い制振効果を得ていること がわかる。この制振性能の違いは，最適レギュレータによる フィードバック補償に起因するものである。このときのタン ク角度のようすを示したものが Fig. 9(b) である. 路面の凹凸 などの外乱によって励起されたスロッシングを制振するため, タンク角度を変化させていることがわかる. また，フィード フォワード補償のみでは, 吸振器のモデル化誤差のために夕 ンク角度を最終的に零にすることができていない。

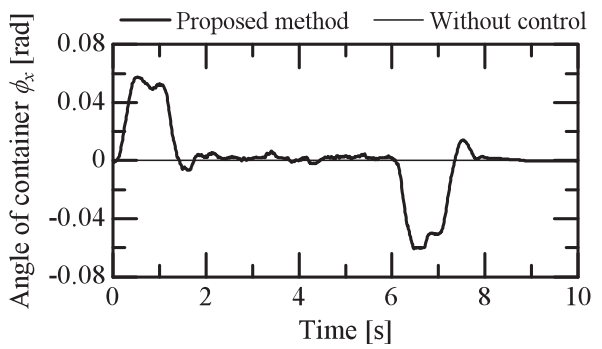

(a) Proposed method

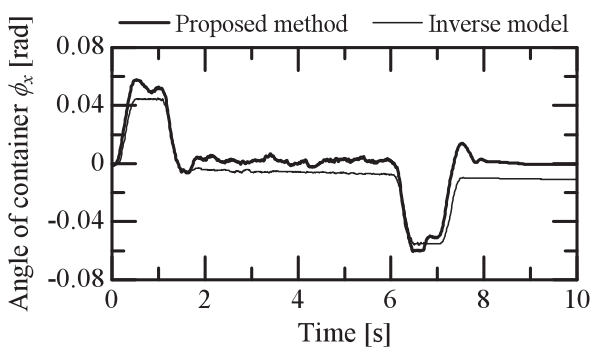

(b) Compared with only inverse model

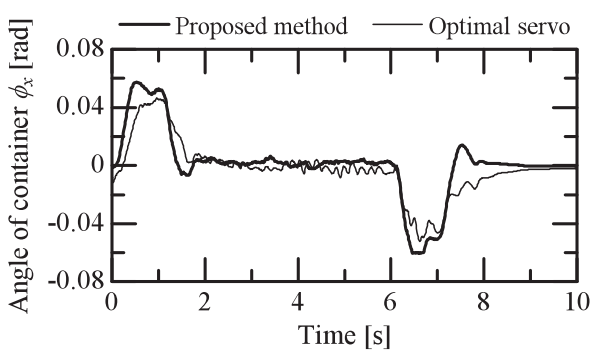

(c) Compared with optimal servo

Fig. 9 Experimental results of angle of container with damping control

Fig. 8(c) では，提案手法と，フィードバック補償器である 最適サーボを用いたものとの比較を行なった．等速走行時や 停止時以降の制振効果において，両者に顕著な差はない。こ の区間では，両者ともフィードバック補償のみが動作している ためである。しかし，加減速時（約 $0.5 \mathrm{~s}$ と約 $6.2 \mathrm{~s}$ ）における 最大液位変動量においては，両者に違いがある，すなわち，提 案手法のほうが最大液位変動量を低く抑えていることがわか る.これはフィードフォワード補償の効果である．Fig. 9(c) のタンク角度の変化のようすを見ると, 提案手法のものは, 波形の立ち上がりならびに立ち下がりが急峻であることがわ かる．フィードバック補償器である最適サーボは，液位変動 量に変化が生じてから制御入力が発生するのに対し，提案手 法では，移動ロボットの加速度情報から直ちに制御入力を発 生させることができるため，より速くて大きな制御入力を発 生させることができている。

制御実験結果において，制御シミュレーション結果のよう に完全に液位変動量を零にすることはできなかった。この原 因としては，以下のことが考えられる．

・走行路面の凹凸ならびに液体タンクの支持機構の剛性不 足（タイミングベルト機構のバックラッシュ含む）によっ 
て, 液体タンクが振動してスロッシングが励振された.

・目標の走行加速度パターンとなるように, PID 制御則を 用いて移動ロボットを制御しているが，駆動輪には少なか らずスリップが生じる。このため, 移動ロボットの加速度 が振動的になり，スロッシングが励振された。

上記は, Fig. 7 と Fig. 8(a) の無制御時の液位変動量を比較す ることによりわかる，等速区間（1.5～6.0s）では, 実験結果 において液面が振動している. この振動は, 約 $3 \mathrm{~Hz}$ の振動数 をもっており，これは，振子モデルで近似した 1 次モードス ロッシングの振動数 $\left(f_{n}=\sqrt{g / l} / 2 \pi=3.14 \mathrm{~Hz}\right)$ に一致する. Fig. 8(a)の提案手法を用いた場合においても，上記の理由に より, 液面が振動したと考えられる。これは, 移動ロボット の走行中（0７.5s）は，液面が振動的になっているが，移動 ロボットの停止後 $(7.5 \mathrm{~s}$ 以降) は, 液面の振動が速やかに制 振されていることから明らかである.

どの程度まで液面を制振すればよいかは，ユーザや使用目 的によって異なる。本実験装置では, 液位変動量が静止液位 (100mm) の $\pm 1 \%$ 以内，すなわち $\pm 1 \mathrm{~mm}$ 以内であれば，目 視で液面振動はないように見える. 提案手法は, 搬送中の全 区間にわたり，この条件をほぼ満たしており，十分な制振効 果が得られているといえる。ただし, さらなる制振性能を得 たい場合には，装置の高剛性化ならびにアクティブ吸振器の 駆動機構の改良が必要である。

\section{6. おわりに}

移動ロボットに搭載した回転式アクティブ吸振器に対し, スロッシングの逆モデルを利用することにより, 制振性能が 向上することを明らかにした。また，最適レギュレータとの 併合システムとすることにより，実験においても良好な制振 結果を得ることができた，曲線経路や斜面路へ本手法を適用 することも可能であるため, 実用性の高い搬送システムを構 築することができる。

本手法は，移動ロボットのみならず，各種クレーンやその 他の搬送システムへも容易に適用することができ, 各種搬送 システムの制振制御ならびに自動化に貢献することができる と考える。

今後は, 装置の高剛性化ならびにアクティブ吸振器の駆動 機構を見直し, さらに良好な制振性能が得られるものに改善 する予定である。

$$
\text { 参 考 文 献 }
$$

1）浜口, 寺嶋, 野村: 各種設計条件における液体タンクの最適搬 送制御，日本機械学会論文集 C 編，60-573，182/189 (1994)

2) 浜口, 山本, 寺嶋：曲線軌道における円筒容器内液体搬送のモ デリングと制御，日本機械学会論文集 C 編，62-601，114/121 (1996)

3）大塚, 岩井, 永本: 強正実性に基づく離散時間適応状態フィー ドバック制御とその液体搬送制御への応用, 日本機械学会論文 集 C 編，63-611，108/113 (1997)

4）矢野，寺嶋：LMI に基づく極配置制約付き混合 $\mathrm{H} 2 / \mathrm{H} \infty$ 制 御による液体搬送制御，日本機械学会論文集 C 編，64-625, 187/194 (1998)
5）浜口, 谷口：曲線軌道設計と台車速度制御による円筒タンク内 液体の制振搬送，日本機械学会論文集 C 編，69-684，194/201 (2003)

6）兼重，西田，寺嶋：振動抑制と目標值追従性を考慮したクレー ンによる液体コンテナ搬送制御, 日本機械学会論文集 C 編, 62-596, 75/82 (1996)

7）福田, 柴田, 鈴木 : 液体容器の液位の振動抑制制御の研究（第 2 報, 容器の回転モーメントを考虑した液体搬送時の液位振動 制御), 日本機械学会論文集 C 編，56-532，99/106 (1990)

8) T. Acarman and U. Ozquner: Rollover Prevention for Heavy Trucks Using Frequency Shaped Sliding Mode Control, Proceedings of 2003 IEEE Conference on Control Applications, 1, 7/12 (2003)

9) Y. Yoshida, M. Hamaguchi and T. Taniguchi: Damping Path Design for Liquid Container Transferred with Wheeled Mobile Robot along Multiple Turn Sections, Proceedings of the 17th IFAC World Congress, 12667/12672 (2008)

10）吉田, 浜口, 谷口: 2 軸回転式アクティブ吸振器付き搬送車によ る液体タンクの制振制御，日本機械学会論文集 $\mathrm{C}$ 編，74-744, 101/107 (2008)

11) N.C. Singer and W.P. Seering: Preshaping Command Inputs to Reduce System Vibration, ASME Journal of Dynamic Systems, Measurement, and Control, 112, 76/82 (1990)

12）古田, 川路，美多，原：メカニカルシステム制御，126/130, オーム社 (1991)

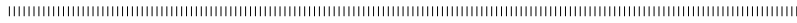

$$
\text { [著 者 紹介] }
$$

浜 口 雅 史（正会員）

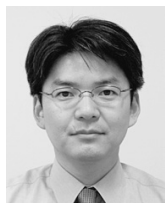

1995 年豊橋技術科学大学大学院工学研究科博士 後期課程総合エネルギー工学専攻修了．同年豊橋 技術科学大学工学部生産システム工学系助手, 98 年徳山工業高等専門学校機械電気工学科助教授, 2001 年島根大学総合理工学部電子制御システム 工学科助教授, 2007 年同准教授, 現在に至る. 移 動ロボットや制振制御に関する研究に従事．博士 (工学).

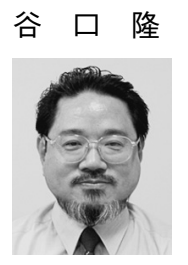

雄 (正会員)

1975 年九州工業大学工学部制御工学科卒業. 同 年九州工業大学工学部制御工学科助手, 89 年山口大 学工学部生産機械工学科助教授, 94 年 California 大学 Berkeley 校客員研究員 (文部省在外研究員), 98 年島根大学総合理工学部電子制御システム工学 科教授，現在に至る。自動走行自動車やメカトロ ニクス機器のインテリジェント制御に関する研究 に従事. 工学博士.

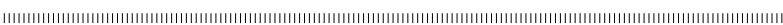

